\title{
Chronic inflammatory diseases are stimulated by current lifestyle: how diet, stress levels and medication prevent our body from recovering
}

\author{
Margarethe M Bosma-den Boer*, Marie-Louise van Wetten and Leo Pruimboom
}

\begin{abstract}
Serhan and colleagues introduced the term "Resoleomics" in 1996 as the process of inflammation resolution. The major discovery of Serhan's work is that onset to conclusion of an inflammation is a controlled process of the immune system (IS) and not simply the consequence of an extinguished or "exhausted" immune reaction. Resoleomics can be considered as the evolutionary mechanism of restoring homeostatic balances after injury, inflammation and infection. Under normal circumstances, Resoleomics should be able to conclude inflammatory responses. Considering the modern pandemic increase of chronic medical and psychiatric illnesses involving chronic inflammation, it has become apparent that Resoleomics is not fulfilling its potential resolving capacity. We suggest that recent drastic changes in lifestyle, including diet and psycho-emotional stress, are responsible for inflammation and for disturbances in Resoleomics. In addition, current interventions, like chronic use of antiinflammatory medication, suppress Resoleomics. These new lifestyle factors, including the use of medication, should be considered health hazards, as they are capable of long-term or chronic activation of the central stress axes. The IS is designed to produce solutions for fast, intensive hazards, not to cope with long-term, chronic stimulation. The never-ending stress factors of recent lifestyle changes have pushed the IS and the central stress system into a constant state of activity, leading to chronically unresolved inflammation and increased vulnerability for chronic disease. Our hypothesis is that modern diet, increased psycho-emotional stress and chronic use of antiinflammatory medication disrupt the natural process of inflammation resolution ie Resoleomics.
\end{abstract}

Keywords: Chronic inflammation, Central stress system, Nutrition, Resoleomics, Sympathetic-adrenal-medulla axis, Hypothalamus-pituitary-adrenal axis, Anti-inflammatory medication, Insulin resistance, Polyunsaturated fatty acids, Glycemic index

\section{Introduction}

The number of people suffering from chronic diseases such as cardiovascular diseases (CVD), diabetes, respiratory diseases, mental disorders, autoimmune diseases (AID) and cancers has increased dramatically over the last three decades. The increasing rates of these chronic systemic illnesses suggest that inflammation $[1,2]$, caused by excessive and inappropriate innate immune system (IIS) activity, is unable to respond appropriately to danger signals that are new in the context of evolution. This leads to unresolved or chronic inflammatory activation in the body.

\footnotetext{
* Correspondence: mirjam@praktijkoberon.nl
University of Girona, Plaça Sant Domènec, 3 Edifici Les Àligues, 17071,

* Correspondence: mirjam@praktijkoberon.nl
University of Girona, Plaça Sant Domènec, 3 Edifici Les Alligues, 17071, Girona, Spain
}

Inflammation is designed to limit invasions and damage after injury, a process which has been essential for the survival of Homo sapiens in the absence of medication such as antibiotics. Recently, it has been discovered that onset to conclusion of an inflammation is a self-limiting and controlled process of the immune system (IS). This process of inflammation resolution is defined by Serhan as Resoleomics [3], a term which will be used throughout this article.

Our genes and physiology, which are still almost identical to those of our hunter-gatherer ancestors of 100,000 years ago, preserve core regulation and recovery processes $[4,5]$. Nowadays our genes operate in an environment which is completely different to the one for which they were designed. 
Modern man is exposed to an environment which has changed enormously since the time of the industrial revolution. In recent decades there has been a tremendous acceleration in innovations which have changed our lives completely. As a consequence, more than $75 \%$ of humans do not meet the minimum requirement of the estimated necessary daily physical activity [6], 72\% of modern food types is new in human evolution [7], psycho-emotional stress has increased and man is exposed to an overwhelming amount of information on a daily basis. All these factors combine to produce an environment full of modern danger signals which continuously activate the IIS and central stress axes. The question is whether the IIS and its natural inflammatory response, Resoleomics, can still function optimally in this modern, fast-changing environment, considering that the IIS is designed to produce short, intensive reactions to acute external danger $[8,9]$. It would seem that in the bodies of people who have adopted a Western lifestyle the inflammatory response is not concluded because of an initial excessive or subnormal onset of the response [10].

This article postulates how triggers from chronic altered diet and psycho-emotional stress negatively influence Resoleomics, thereby increasing susceptibility to the development of chronic, low-grade, inflammation-based diseases due to the constant activation of both the central stress axes and the IIS. In addition, an attempt is made to demonstrate the ways in which the use of anti-inflammatory medication could influence Resoleomics.

\section{Resoleomics, a self-limiting process of inflammation}

Serhan and his colleagues [3] introduced the term Resoleomics to describe a self-limiting process of inflammation, executed and controlled by the innate immune system (IIS) and regulated by the sympathetic nervous system (SNS) and the hypothalamus-pituitary-adrenal (HPA) axis. This process controls inflammation using metabolites produced from arachidonic acid (AA), eicosapentaenoic acid (EPA) and docosahexenoic acid (DHA). Resoleomics operates locally when polymorphonuclear neutrophils (PMNs) are attracted by increased pro-inflammatory cytokine and eicosanoids production during microbial invasion, wound healing or chemical injury. The function is to limit the inflammation response. The central control system of the inflammatory reaction is very complex. Local and central processes influence each other and both are responsible for an optimal resolving response (Figure 1). The local process can be divided into three phases [11] (Figure 2):

1. Initiation phase

2. Resolution phase

3. Termination phase

\section{Initiation phase}

Pro-inflammatory eicosanoids, like leukotrienes B4 (LTB4) and prostaglandins (PGs) initiate the inflammatory response. PMNs generate LTB4 and PGE2 from precursor AA with the use of lipoxygenase-5 (LOX-5) and cyclo-oxygenase 2 (COX-2). Both eicosanoids enhance inflammation, LTB4 being the strongest chemotoxic compound of cytotoxic neutrophils. PGE2 and/ or PGD2, although initially pro-inflammatory, determine the switch to the next phase, the resolution of the inflammation.

\section{Resolution phase}

This phase starts with the Eicosanoid Switch to resolution. When the PGE2 and/or PGD2 level is equal to the level of LTB4, the PMNs activate the switch from pro-inflammatory to anti-inflammatory eicosanoids production by limiting the production of LOX-5. This switch is responsible for the production of anti-inflammatory lipoxins (LXs) from AA through activation of lipoxygenase -12 (LOX12), lipoxygenase-15 (LOX-15) and acetylated COX-2 $[13,14]$. This last mechanism has been found to be responsible for the production of more stable aspirin-triggered LXs (ATLs) with a longer half-value period [15]. Other resolving metabolites that support LXs are resolvins, (neuro)protectins and maresins produced from respectively EPA and DHA $[11,16]$. A second substantial increase of COX-2 activity will produce anti-inflammatory PGs (PGD2 and PGF2a) during this phase [17].

\section{Termination phase}

This phase starts when the Stop Signal takes place. This happens when sufficient anti-inflammatory mediators such as LXs are available to stop the pro-inflammatory process $[13,14]$. LXs are capable of inhibiting both PMN infiltration and the activity of cytotoxic cells of the ISS, inducing phagocytosis to clear debris by non-cytoxic macrophages and attenuating an accumulation of the proinflammatory transcription factors, ie nuclear factorkappaB (NF-kB) and activator protein 1 (AP-1) $[18,19]$.

\section{Central stress axes and Resoleomics}

This section deals solely with the effect of the sympathetic, parasympathetic and the HPA axis on Resoleomics. The systemic stress system is closely linked to the IIS via the stress axes of our body. Anything that can activate the sympathetic-adrenal-medulla (SAM) and HPA axes will have its effect on the IIS [20] and therefore on Resoleomics. Seen in reverse, it is precisely the IIS that can trigger stress axes, inducing a systemic stress reaction in the body [21]. In the SNS, which initially activates the IIS, inhibition of the IIS is provided by the strong anti-inflammatory neurotransmitter acetylcholine $(\mathrm{ACh})$, produced by the parasympathetic nervous system [22]. 


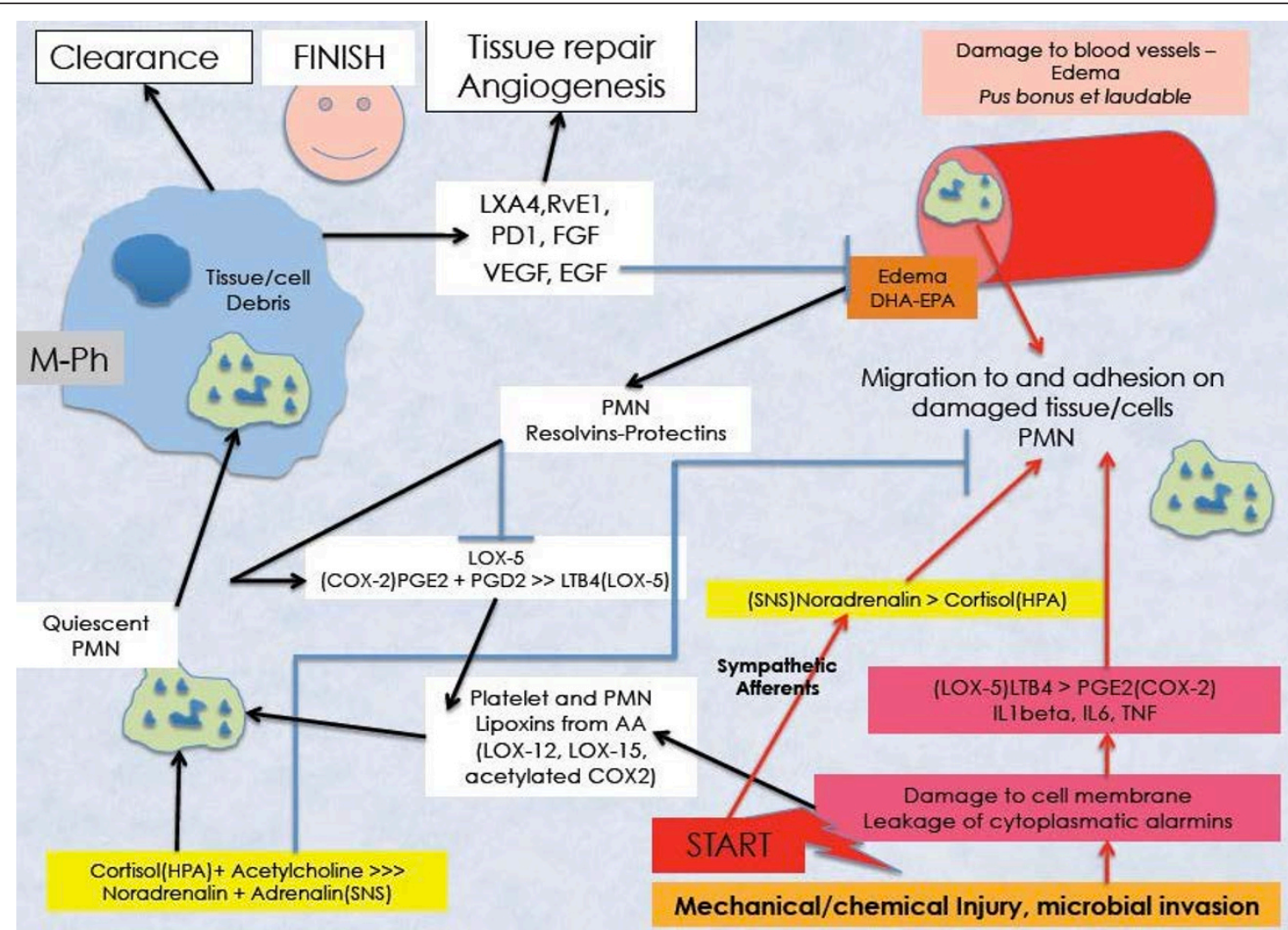

Figure 1 Start and finish of a physiological inflammatory reaction in wound healing and situations of microbial challenge. Cellular damage and leakage of alarmins attract neutrophils to the damaged area (PMN's). Sympathetic afferents activate the locus coeruleus (central nucleus of the sympathetic nervous system, SNS) and Noradrenaline (Norepinephrine, NE) is released. The released NE activates the adrenal medulla inducing the production of systemic catecholamins that supports the activation of the PMN. Damaged blood vessels are a source of an omega 3 rich edema (EPA and DHA). DHA and EPA inhibit LOX-5 directly and through conversion into resolvins and protectins. Both PGE2 and PGD2, produced by the breakdown of AA by COX-2 activity, will now override the strong chemotaxic effect of LTB4. The combined action of protectins, resolvins and lipoxins produced out of AA will put a hold on the pro-inflammatory activity of PMN's, which is supported by the increased production of systemic cortisol. Cortisol further activates macrophages (M-Ph) to phagocytose issue debris and quiet PMN by releasing substances such as LXA4, resolvin E1 (RvE1), prostanoid D1 (PD1), fibroblast growth factor (FGF), vascular endothelial growth factor (VEGF) and epithelial growth factor (EGF) at the same time. Further edema leakage will be stopped, whereas angiogenesis and production of connective tissue will take place, finishing the inflammatory reaction and starting the production of new tissue.

The systemic stress reaction follows a two-wave pattern. Activation of the SAM axis is considered the first wave, giving rise to the excretion of brain norepinephrine (NE) by the Locus Coeruleus (LC). The descending pathway activates sympathetic motor neurons in the medulla oblongata, which stimulate the adrenal glands (through sympathetic efferent nerves). The adrenal gland will now excrete catecholamines, which activate and induce proliferation of ISS cells. NF-kB increases pro-inflammatory cytokines production, such as interleukin 1-beta (IL1- $\beta$ ), interleukin 6 (IL-6) and tumor necrosis factor (TNF). Both the IIS and Th1 of the adaptive IS contain receptors sensitive to catecholamines. Cerebral catecholamines affect the activity of spleen, thymus, bone marrow and lymphoid nodes [23]. NE has been shown to activate the IIS at the onset of inflammation, while long-term activation of the SNS induces IIS inhibition [24].

The second wave of the systemic stress reaction corresponds with the activation of the HPA axis, with glucocorticoids (GCs) as end product. Cortisol is capable of inhibiting the IIS through the upward regulation of inhibiting factor kappa B (IkB), while informing the immunological cortex through the migration of different immune cells to the brain $[25,26]$. Cortisol, the regulator of the IIS response, can guide the inflammation into resolution phase. Termination is instigated when cortisol "overrules" the NE effect on NF-kB signalling through genetic influence and reduction of transcription of the NF-kB sensitive pro-inflammatory gene, resulting in the finalization of the inflammatory response (Figure 2). 


\section{Phases of Inflammation and Stress Axes}

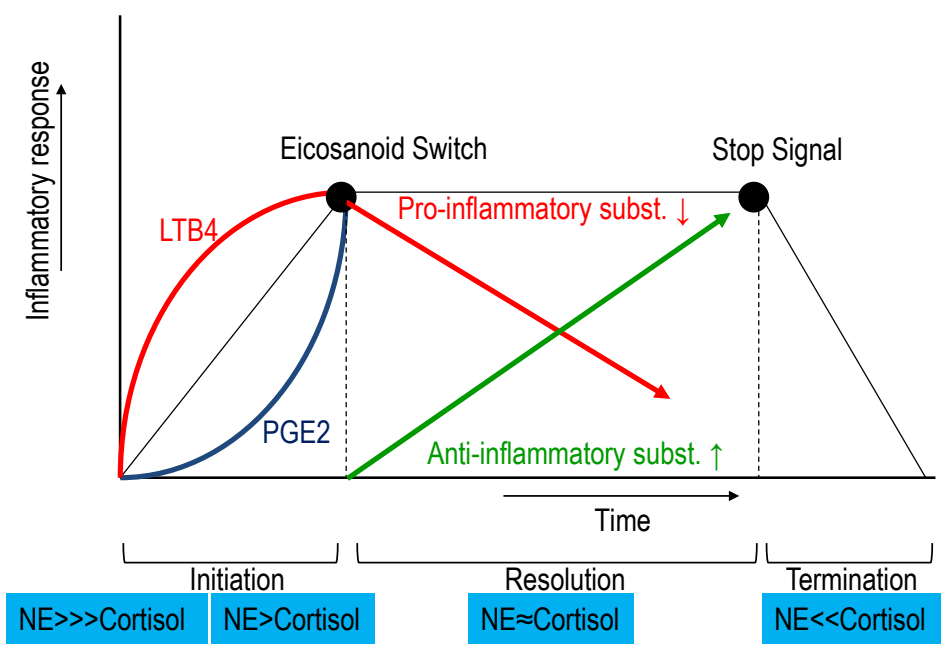

Figure $\mathbf{2}$ Inflammation is a controlled process with an initiation, resolution and termination phase. After microbial invasion, lesion or chemical injury, the initiation phase starts with the production of pro-inflammatory mediators like LTB4 and PG2. These mediators increase inflammation until the Eicosanoid Switch, the end of the initiation phase, takes place. This occurs when the level of PGE2 plus PGD2 is equal to the LTB4 level. The resolution phase is entered, triggering the generation of anti-inflammatory mediators like LK, resolvins, protectins, maresins, PGD2 and PGF2a. When the total level of anti-inflammatory mediators exceeds the level of LTB4 the Stop Signal takes place. This is the last phase, the inflammation will be terminated by clearing the affected area [11]. The stress hormones produced by the systemic stress axes have a direct effect on the inflammation phases. A microbial invasion, lesion or injury sends off an alarm in the body, setting off the systemic stress system which produces NE as response and tunes the system to insulin and cortisol resistance [12]. The Eicosanoids Switch to resolution can only take place when NE is equal to the level of cortisol plus insulin and when cortisol sensitivity is recovered. The Stop Signal requires a low level of NE and normalized cortisol sensitivity. The termination phase is entered when the stress axes are switched off.

This "termination" effect of cortisol is normally supported by a compensatory anti-inflammatory response through activation of the vagal anti-inflammatory loop [27]. The resulting production of ACh inhibits the IS through the alfa-7-nicotin-Acetylcholinergic Receptor ( $\alpha 7 \mathrm{nAChR}$ ) [28] (Figure 1).

The SNS (NE) increases the initial pro-inflammatory immune response in the initiation phase, whereas delayed cortisol response, induced by the HPA axis, inhibits the pro-inflammatory response [29]. Integrity of the SAM axis with its NE response/reaction is necessary for an adequate initial inflammatory response [30]. At the beginning of the initiation phase, there is resistance to both cortisol and insulin in order to allow for the activation of the IIS [12]. At the end of this phase, cortisol sensitivity and insulin sensitivity should be recovered to facilitate the Eicosanoid Switch to the resolution phase.

Chronic stress exposure reduces the capacity to mount an acute stress response [31], resulting in an inadequate pro-inflammatory response. Chronic (psycho-emotional) stress situations can be responsible for the continuous production of catecholamines by the SAM axis. People suffering from "perpetual stress", for example the parents of a child with cancer, showed chronic, increased levels of circulating pro-inflammatory cytokines [26]. This situation requires a high level of energy expenditure. The metabolic rate is increased to provide extra energy for the brain (arousal of all senses), the heart muscle and the locomotive system. The existing cells from the IIS are activated and will proliferate (relatively low energy expenditure), whereas proliferation of new immune cells (much more costly energy expenditure) will be blocked. Further consequences of chronic SAM activity are narrowing of the cell spectrum of the IIS and complete loss of activity of the Th1 section of the adaptive IS, leading to an insufficient capability to fight viruses, (pre)neoplastic cells and intracellularly presented pathogens [31].

An inflammatory response leading to solution depends on the sensitivity of glucocorticoid receptors (GR) and catecholamine receptors of the IIS [32]. Factors such as stress endured early in life, trauma and polymorphisms are possible risk factors for loss of GR and catecholamine sensitivity [33-35].

Suboptimal inflammatory response as a consequence of chronic stress prevents the Eicosanoid Switch from functioning, since the switch to the resolution phase requires recovered cortisol and insulin sensitivity. The initiation phase should have a maximum duration of 8 to $12 \mathrm{hrs}$. PMN number and activation levels should reach their 
maximum during this phase; longer duration caused by chronic stress could produce secondary damage to neighbouring tissues due to the strong cytotoxic effects of activated PMNs [11]. Supramaximal activation of PMNs could sensitize the adapted IS if contact time between self-antigens and the IS is significantly increased [11,29].

The crosstalk between the IS and stress axes is further evidenced by the fact that acute production of high levels of catecholamines activate the IIS strongly [23], whereas eicosanoids produced from AA induce the production of local and systemic catecholamines [36]. Long-term activation may lead to catecholamine resistance and lack of eicosanoid production. This situation, combined with the aforementioned possibility of resistance to insulin and cortisol, provokes a suboptimal inflammatory response and consequently the perpetuation and development of lowgrade inflammation [26,37].

\section{Nutritional factors and Resoleomics}

Several dietary factors influence the activity of the IIS and the function of a wide range of hormones, including cortisol, insulin and catecholamines. The dramatic changes in dietary composition since the agricultural revolution (some 10,000 years ago) and, to a greater extent, since the industrial revolution (some 200 years ago) have turned the intake of food into a common daily danger and therefore a cause of continuous systemic stress. Some of these changes include an increase in the omega 6/omega 3 fatty acid ratio, a high intake of saturated fatty acids (SFA) and refined carbohydrates, the introduction of industrially produced trans fatty acids, a lower intake of vitamins $\mathrm{D}$ and $\mathrm{K}$, imbalanced intake of antioxidants, high intake of anti-nutrients (eg lectines, saponins) and an altered intake of dietary fibre [38].

The following section will discuss the impact of the changed ratio of polyunsaturated fatty acids (PUFAs) and the intake of food with a high glycemic load on Resoleomics. The pro-inflammatory effects of anti-nutrients present in cereals [39], potatoes [40], legumes [41], and tomato have previously been extensively reviewed [7].

\section{Role of PUFAs in inflammation}

The intake ratio of $\alpha$-linoleic acid (LA) (omega 6), $\alpha$-linolenic acid (ALA) (omega 3), docosahexaenoic acid (DHA) and eicosapentaenoic acid (EPA) in the Western diet has changed dramatically compared to the estimated intake ratio of hunter-gatherer diets from 2-3:1 to 10-20:1 in the contemporary diet $[42,43]$. All of these PUFAs are essential for normal Resoleomics response, as they function as precursors for the special small mediators responsible for the instigation and conclusion of the inflammatory response. One of the toxic changes in fatty acid composition of food corresponds to the increased intake of LA since the production of vegetable oils in 1913. Increased
LA levels affect the inflammation process in three ways (Figure 3):

1. Increase of the omega 6/omega 3 fatty acid ratio

2. Altered AA level

3. Increases of inflammatory compounds, leukotoxins (LK) production

\section{Increased omega 6/omega 3 fatty acid ratio}

The inflammatory effect of a high omega 6/omega 3 fatty acid ratio during inflammation has been demonstrated in recent human studies $[44,45]$, in vitro studies $[46,47]$ and animal studies $[48,49]$. The higher LA levels in phospholipids in plasma and cell membranes seem to be a major factor responsible for incomplete Resoleomics reactions. Higher intake of omega 3 fatty acids in the form of DHA and EPA regulate the production of pro-inflammatory cytokines and decrease LA levels in phospholipids in plasma and cell membranes $[46,48]$. The conversion of LA and ALA into respectively AA, DHA and EPA depend on the same enzymes in the desaturase and elongase cascade, with $\delta$-6-desaturase as the rate-limiting enzyme (Figure 4) [50].

Human trials investigating the effects of omega 3 dietary supplements showed significant improvements of symptoms in patients suffering from diseases such as RA, inflammatory bowel disease, asthma, psoriasis, breast cancer and CVD. However, full remission of symptoms was not achieved [43,51]. Our conclusion is that an increased intake of omega 3 alone is not enough to restore Resoleomics; the intake of LA must be decreased as well.

\section{$L A$ effect on $A A$ level}

Higher AA levels in plasma result in more adequate inflammatory reactions, since AA is a precursor of proand anti-inflammatory substances within the self-limiting inflammatory process [52]. LA is the precursor for AA in the desaturase/elongase conversion (Figure 4). Theoretically, LA could be the source of a sufficient level of endogenous AA. However, higher intake of LA does not deliver increased levels of AA in comparison to low intake $[53,54]$. To achieve the required AA level, AA should be present in the regular diet [45]. The combined situation of AA deficiency together with a reduced intake of omega 3 fatty acids such as DHA and EPA (necessary for the flip flop reaction of LOX-5 and the Eicosanoid Switch [3]), enable a perpetuation of the pro-inflammatory initiation phase and therefore of chronic inflammation.

\section{Increased production of leukotoxin}

The third harmful effect of high LA intake is the possible production of so-called leukotoxins (LK). High LA levels are metabolized by CYP2C9 in the liver into biologically active oxidation products known as LK and leukotoxin diol (LTD). These metabolites promote oxidative stress responses and the activation of NFkB and AP-1, increasing the systemic release of pro-inflammatory cytokines [55]. LK and LTD are toxic for T cells, and can kill these cells 


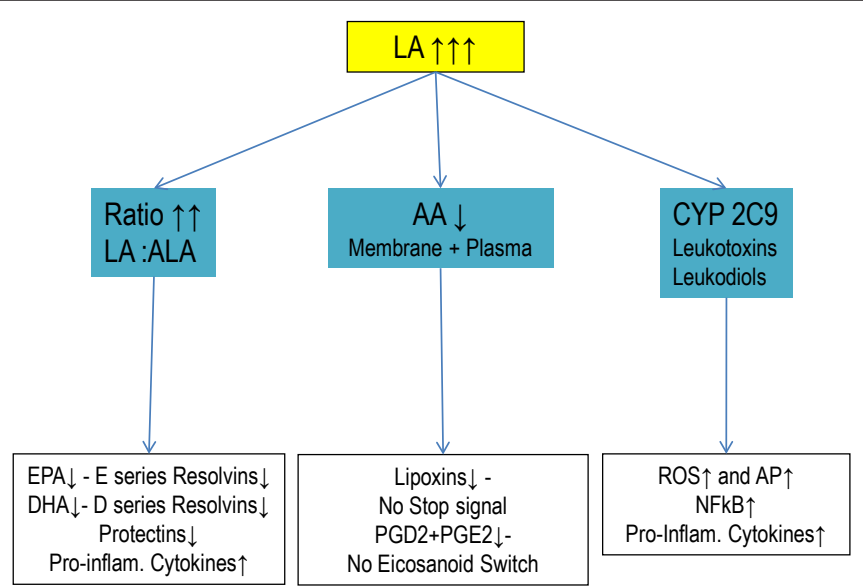

Figure 3 Summary of the effects of high LA intake on Resoleomics.

with pathways resembling necrosis and programmed cell death [56].

\section{Role of high glycemic food in Inflammation}

An abundant intake of high glycemic food appears to be related to an increased susceptibility to the development of chronic inflammation, as has been demonstrated by several research groups [57-59]. The consequences of a high carbohydrate diet are complex and multiple. The pathways leading to disturbances of normal inflammation are:

1. High glycemic food intake increases inflammation markers

2. High glycemic food intake causes hyperglycemia and hyperinsulinemia leading to disturbed balances in insulin growth factor-1 (IGF-1) and androgens
3. Chronic intake of high glycemic food causes hypoglycemia, which triggers central stress axes

High Glycemic food increases inflammation markers

Various clinical trials have shown that an abundant intake of high glycemic food increases inflammatory markers and markers of metabolic syndrome such as postprandial NFkB in mononuclear cells [57], high sensitive-C-Reactive Protein (hs-CRP)[58], interleukin (IL)-6, IL-7, IL-18 [60], levels of free radicals [59], cholesterol, triglycerides [61] and even blood pressure [62]. Changes incurred by following a low glycemic diet include improved insulin sensitivity, lower blood pressure and total cholesterol, which are all key markers of the metabolic syndrome $[58,60,61]$. The high glucose-induced inflammatory response is accompanied by hyperinsulinemia and insulin resistance, characteristic for

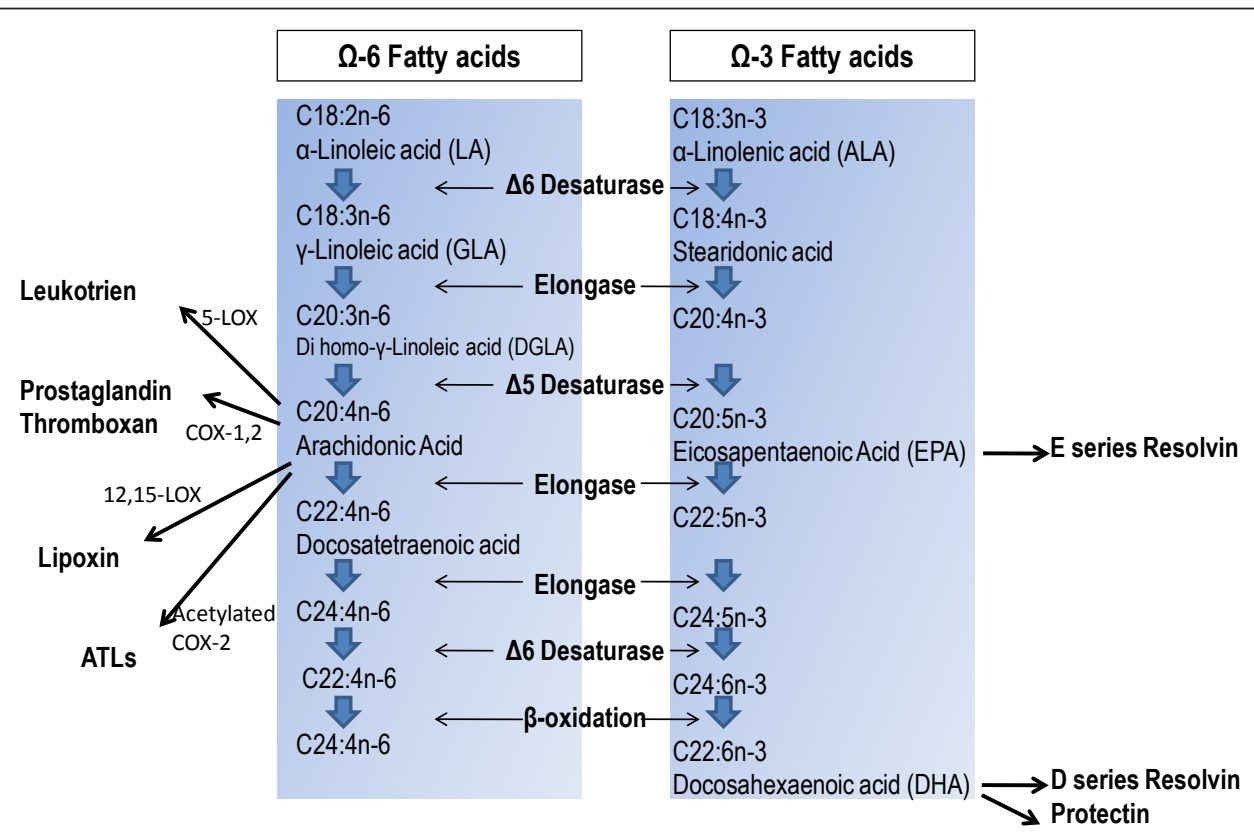

Figure 4 Synthesis of unsaturated fatty acids in mammals by Desaturase and Elongase. 
people suffering from obesity $[57,59]$. Increased hsCRP values, hyperinsulinemia and insulin resistance are strongly related to CVD risk [60]. Glycemic index (GI) and glycemic load (GL) have therefore been proposed as biomarkers and predictors for (chronic) inflammation [63].

\section{Hyperglycemia and hyperinsulinemia}

Cordain demonstrated that high glycemic food is a potential risk factor for inflammation through disturbed signalling of mechanisms as a result of hyperglycemia and hyperinsulinemia [64] (Figure 5b). Long exposure to high glucose levels in blood, which leads to a slow recovery of the homeostasis, makes tissues vulnerable to disease [65]. High plasma insulin can increase the production of IGF-1 and androgens. Both hormones are related to disorders such as polycystic ovarian syndrome (PCOS) [66], epithelial cell cancer (breast, prostate, colon) [67,68], acne [69], androgenic alopecia [70], and acanthosis nigricans [71]. Several pathways in this respect have been previously described in medical literature, but these go beyond the scope of this article.

\section{Hypoglycemia triggers the systemic stress system}

As previously mentioned, intake of a high glycemic diet can cause hyperglycemia and hyperinsulinemia. Hyperglycemia will push abundant glucose via insulin into muscle and adipocytes at the instigation of the inflammatory process. However, continuous intake of high glycemic food results in reactive hypoglycemia, ie an energy-deficient situation which threatens the homeostasis of the body. As a consequence, the brain will maintain its own energy supply aimed at the survival of the organism (the selfish brain) [25]. To ensure sufficient energy supply, the brain activates its systemic stress system to induce gluconeogenesis (Figure 5a). Excreted catecholamines and cortisol will mobilize extra energy, which is allocated with priority to the brain and to the activated IS, at the expense of other body tissues [72].

On the basis of the above information and other referenced data, it seems plausible to state that aspects of the Western diet, of the modern industrialised environment and of their resultant lifestyles form a chronic danger to the body, triggering both the central stress axes and the IIS into a state of chronic activity. This state seems to be a direct cause of the development of low-grade inflammation and consequently of chronic inflammatory diseases (Figure 5a).

\section{Impact of current medication on Resoleomics}

The role of the IIS is to limit the damage of inflammation in acute situations. Anti-inflammatory medication can be used to dampen the immune response. Nowadays, as a result of lifestyle changes, man is exposed to chronic inflammation and consequently to the chronic use of anti-inflammatory medication, much of which in fact suppresses Resoleomics. Current medication used to treat chronic inflammatory diseases does suppress the symptoms of inflammation, but complete remission of the disease is seldom realized [73]. Resoleomics is hindered and complete resolution of the inflammation does not take place. Modern chronic inflammatory diseases are treated by several groups of medication. In this article we focus on rheumatoid arthritis (RA) medication as an example. Four groups of anti-inflammatory RA medication are taken into account: the prostaglandin inhibitors [Nonsteroidal anti-inflammatory drugs [NSAIDs: Aspirin (ASA) and COX-inhibitors], the Glucocorticoids (GCs), the Disease Modifying Drugs [DMARDs: Methotrexate (MTX) and Sulfasalazine (SSZ)] and the cytokine blockers [Biological agents: anti TNF- $\alpha$ lpha and IL-1 blockers]. The mechanisms of action and possible effects on the IIS and Resoleomics are summarized from literature (see Table 1). Most current therapies target the IIS in an attempt to inhibit the production of pro-inflammatory chemical mediators (Table 1). However, an equally important target is the active induction of proresolution programs by stromal cells such as fibroblasts within the inflamed tissues [74]. Inhibition of MIF [75] and production of $\mathrm{NO}$ [76] are not addressed in this article.

\section{Positive effect of ASA and GCs on Resoleomics}

Medical intervention should stimulate the endogenous pathways of resolution and two drugs already known to possess these qualities are central to contemporary medicine: glucocorticoids (GCs) [77] and aspirin (ASA) $[106,107]$. It is apparent that ASA and GCs have a positive effect on Resoleomics, while other medications prolong the initiation phase, tempering and/or blocking the resolution and termination phase of Resoleomics in various ways (Table 1). The positive effect of ASA on Resoleomics can be ascribed to its ability to produce ASA-triggered lipoxins (ATLs) through acetylation (and not through an irreversible inhibition) of the COX-2 enzymes [78]. These ATLs show many proresolving properties, which are essential in the resolution and termination phase of the inflammation process $[79,108]$. Long-term intake of high doses of ASA blocks PGE2 production and initiates the resolution phase without affecting the biosynthesis of other proresolving mediators [108]. Low and high doses of ASA increase the production of lipoxin A4 (LXA4) and 15epi-LXA4 in the rat brain, suggesting that ASA could protect against neuroinflammation [109]. However, because of its side effects, ASA is no longer the treatment of choice for RA. In high doses, inhibition of the COX-1 enzyme by ASA is responsible for damage to the stomach lining.

ASA and also GCs activate the ALX/FRP2 receptor, making them the ideal collaborator in the resolution 


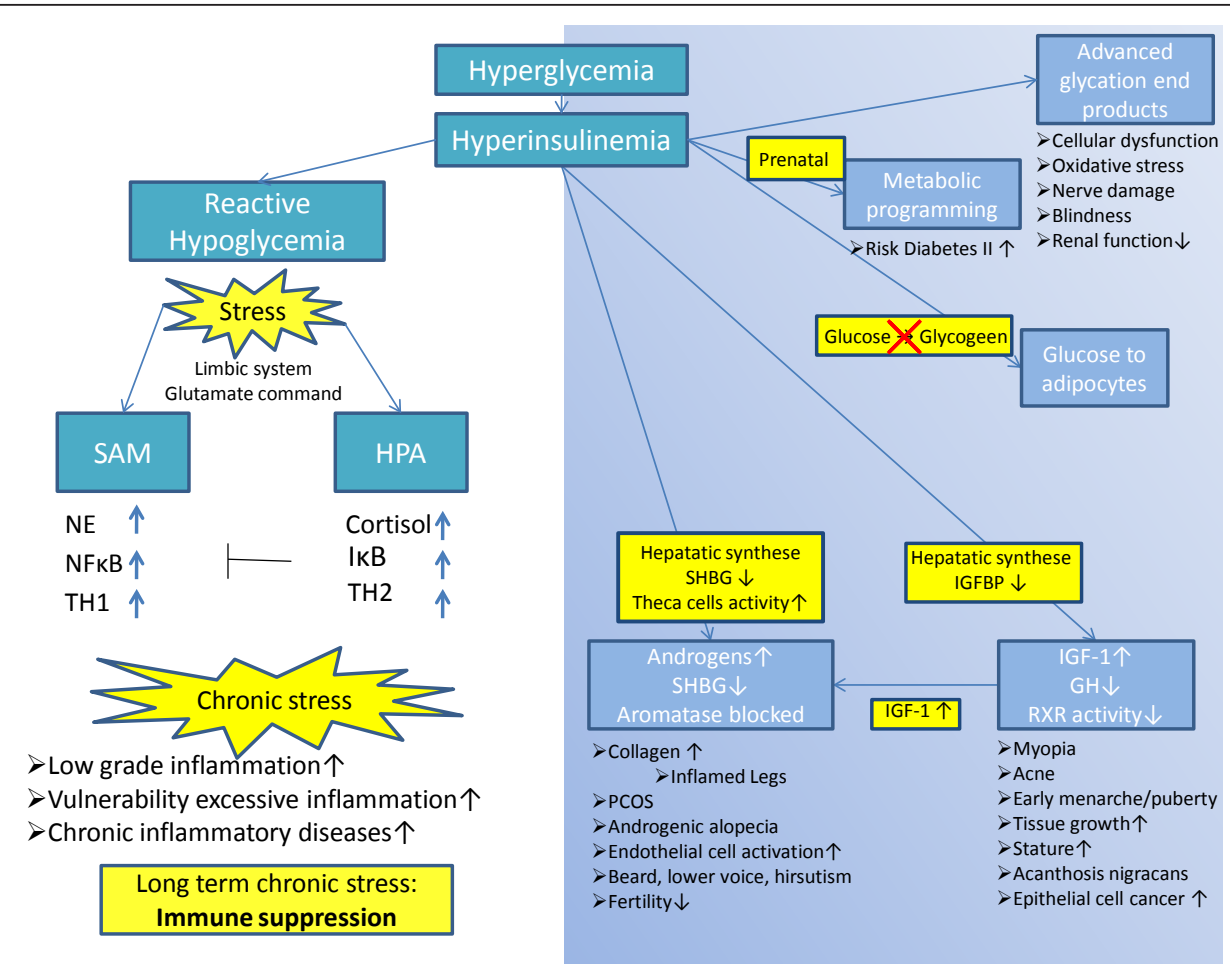

Figure 5 High glycemic food intake could cause inflammation and diseases as a result of hyperinsulinemia. The pathways in the shaded area have been extensively described by Cordain [64] (part B). Part A: The consequential reactive hyperglycemia is another deleterious pathway. Hyperglycemia is a danger signal, which activates the systemic stress system. Chronic activation will suppress the IIS, resulting in low grade inflammation and an increased vulnerability for excessive inflammation.

process [77]. GCs-induced annexin-1 protein (ANXA1) $[110,111]$ as well as ASA-induced ATLs act on the same ALX/FPR2 receptor and dampen PMN infiltration $[77,80]$. ANXA1 also inhibits the phospholipids A2 enzyme (PLA2). Reduced PLA2 activity appears to reduce AA release from the cell membrane [32,112], which possibly leads to decreased levels of both PGs and LTs and to the delay of resolution. Besides their anti-inflammatory effects, GCs have a positive influence on resolution by enhancing macrophage migration and phagocytosis [11,113].

\section{Adverse effects of medication on Resoleomics}

The use of anti-inflammatory medication without the capacity to induce (complete) resolution should be considered solution-toxic, ie hindering Resoleomics. NSAIDs are strong inhibitors of COX-2 and less of COX-1 enzymes [114]. Almost complete COX-2 inhibition decreases the PGs synthesis, and consequently leads to a higher production of LTs via LOX-5 in PMNs [115]. PGE2 and PgD2 decrease the activity of LOX-5, decreasing neutrophil activity and facilitating the end of the inflammatory phase and the instigation of resolution.

Immune-suppressors such as SSZ (and less powerful GCs) almost completely block NF-kB transcription, leading to insufficient cytokine production and suboptimal inflammation [86]. Again the resolution process will not be completed, with perpetuation of inflammation as the logical consequence.

Perhaps the most deleterious drugs, interfering negatively with resolution, are TNF-alpha inhibitors such as anti TNF-alpha and MTX. MTX inhibits the proliferation of the IIS cells, decreasing the production and accumulation of adenosine within the IS cells $[88,116]$. These effects lead to rapid anti-inflammatory effects and symptom release. However, because of its side effects and incomplete resolution, this medication is qualified as solutiontoxic. This conclusion is supported by many patients who have discontinued this treatment [73].

Another group of possible solution-toxic drugs are biological agents with an inhibiting effect on TNF-alpha and IL1. Biological agents together with DMARDS (Table 1) are strong anti-inflammatory compounds, decreasing the production of pro-inflammatory cytokines. The absence or insufficient activity of pro-inflammatory cytokines decreases cell communication and induction of COX-2 in activated neutrophils. This can lead to less production of resolution substances such as PgE2, PgD2 and lipoxins $[54,103]$. Furthermore, DMARDs and biological agents appear to reduce the functioning and number of IIS cells, 


\begin{tabular}{|c|c|c|c|}
\hline Medication & Mechanism of action & $\begin{array}{l}\text { Current RA treatment effects on } \\
\text { Immune System Cells }\end{array}$ & $\begin{array}{l}\text { Predicted effects on } \\
\text { ResoleomicsPhase 1: initiation, Phase } \\
\text { 2: resolution, Phase 3: termination }\end{array}$ \\
\hline $\begin{array}{l}\text { Aspirin (ASA) } \\
{[11,14,32,77-83]}\end{array}$ & $\begin{array}{l}\text { COX-1 inhibition, COX-2 acetylationPGE2 } \\
\downarrow A T L s(15 \text {-epi-LX) } \uparrow A c t i v a t i o n \text { of the } \\
\text { ALX/FPR2 receptor } \uparrow P L A 2 \downarrow \text { : free AA, } \\
\text { PGE \& LT } \downarrow\end{array}$ & $\begin{array}{l}\text { PMN infiltration } \downarrow \text {, PGEs } \downarrow \text {, chemokines } \\
\downarrow \text { Leucocyte accumulation } \downarrow \text { Neutrophil } \\
\text { recruitment } \downarrow \text { Vascular permeability } \\
\downarrow \text { Nonphlogistic phagocytosis of } \\
\text { apoptoticneutrophils } \uparrow\end{array}$ & $\begin{array}{l}\text { Negative: } P G<L T \text { levels: Phase } 1 \\
\uparrow \text { Positive: PG not completely } \downarrow \text { : switch } \\
\text { from phase } 1 \text { to phase } 2 \uparrow \text { Positive: ATLs } \\
\uparrow: \text { phase } 2 \uparrow \text { and } 3 \uparrow\end{array}$ \\
\hline $\begin{array}{l}\text { NSAIDs:COX- } \\
\text { inhibitors }[84,85]\end{array}$ & $\begin{array}{l}\text { COX-2 inhibition > COX-1 inhibitionPGE2 } \\
\downarrow, \text { LTB4 } \uparrow \text { PGF } 2 \alpha, \text { PGD2 } \downarrow\end{array}$ & $\begin{array}{l}\text { COX-2 expression macrophages } \downarrow \text { : } \\
\text { Chemotaxis of neutrophils, eosinophils } \\
\text { and monocytes into synovium } \downarrow\end{array}$ & $\begin{array}{l}\text { Negative: PG }<\text { LTB4 levels: Phase } 1 \\
\uparrow \text { Switch from phase } 1 \text { to } 2 \downarrow \text { Switch from } \\
\text { phase } 2 \text { to } 3 \downarrow\end{array}$ \\
\hline $\begin{array}{l}\text { Glucocorticosteroid } \\
(\mathrm{GCs})[32,80,86,87]\end{array}$ & $\begin{array}{l}\text { Transcription of IKB } \uparrow: \text { NFkB } \\
\downarrow \text { Transcription by GCR \&CREB-binding } \\
\text { protein (CBP) } \downarrow \text { PLA2 } \downarrow \text { : free AA, PGE \& LT } \\
\downarrow \text { Annexin- } \uparrow \text { Activation of the ALX/FPR2 } \\
\text { receptor } \uparrow\end{array}$ & $\begin{array}{l}\text { PMN infiltration } \downarrow \text {, PGEs } \downarrow \text {, chemokines } \\
\downarrow \text { Leucocyte accumulation } \downarrow \text { Neutrophil } \\
\text { recruitment } \downarrow \text { NFkB } \text { - transcription } \\
\downarrow \text { Expression of inflammatory genes } \\
\downarrow \text { Macrophage migration and } \\
\text { phagocytosis } \uparrow\end{array}$ & $\begin{array}{l}\text { Negative: PGE, LT } \downarrow \text { : switch from phase } 1 \\
\text { to } 2 \downarrow \text { Cortisol resistance: switch from } \\
\text { phase } 1 \text { to phase } 2 \downarrow \text { or no } \\
\text { switchLipoxins } \downarrow \text { : switch from phase } 2 \text { to } \\
3 \downarrow\end{array}$ \\
\hline $\begin{array}{l}\text { DMARDs: } \\
\text { Methotrexate MTX } \\
\text { [88-102] }\end{array}$ & $\begin{array}{l}\text { Folate analogs:1. Folate-dependent } \\
\text { enzymes } \downarrow: 1 \text { a. Thymidylate synthetase } 1 b \text {. } \\
\text { AICAR transformylase1c. Dihydrofolate } \\
\text { reductase2. Cytosol peroxide (ROS) } \uparrow\end{array}$ & $\begin{array}{l}\text { Ad 1a. Synthesis of DNA \& RNA } \downarrow \text { T-cell- } \\
\text { proliferation \& protein- \& cytokine- } \\
\text { expression by T-cells } \downarrow \text {, LT \& IL-1 } \downarrow \text { Ad 1b. } \\
\text { Adenosine } \uparrow: \text { NK-cell, monocytes \& } \\
\text { macrophages functioning } \downarrow \text {, Cytokine } \\
\text { synthesis of TNF- } \alpha, \text { IL-1, IL-6 \& IL-8 } \downarrow\end{array}$ & \\
\hline $\begin{array}{l}\text { 1c. THF } \downarrow \text { : purine \& } \\
\text { pyrimidine } \downarrow \text { Ad } 2 \text {. } \\
\text { T-cell apoptosis } \uparrow\end{array}$ & $\begin{array}{l}\text { Negative: cytokines, T-cell activity } \downarrow \text {, LT } \downarrow \text { : } \\
\text { switch from phase } 1 \text { to } 2 \downarrow \text { or no switch }\end{array}$ & & \\
\hline $\begin{array}{l}\text { DMARDs: } \\
\text { Sulphasalazine (SSZ) } \\
\text { [86] }\end{array}$ & $\begin{array}{l}\text { SSZ: strong and potent inhibitor of } \\
\text { NFkB-activation5-amino acytelate (5- } \\
\text { ASA): PG } \downarrow \text { sulpha-pyridine }\end{array}$ & $\begin{array}{l}\text { Less NFkB activation } \downarrow \text { : IL-2 of activated } \\
\text { T-cells } \downarrow \text {, TNF alfa \& IL-1 macro-phages } \downarrow \text {, } \\
\text { Antibody in plasma cells } \downarrow \text {, Neutrophils, } \\
\text { monocytes, macrohages, granulocyte } \\
\text { activation } \downarrow \text {, IKB } \downarrow \text { : NFkB translocation } \downarrow \\
\& \text { transcription of cytokines, adhesion } \\
\text { molecules, chemokines } \downarrow \text { : COX-2 \& PG } \downarrow\end{array}$ & $\begin{array}{l}\text { Negative: Immune cell activity } \downarrow \text { : switch } \\
\text { from phase } 1 \text { to } 2 \downarrow\end{array}$ \\
\hline $\begin{array}{l}\text { Biological agents: } \\
\text { Anti TNF-alpha } \\
\text { [54,103-105] }\end{array}$ & $\begin{array}{l}\text { TNF-alfa signalling of mono's, PMN's, T- } \\
\text { cells, endothelial cells, synovial fibroblasts } \\
\& \text { adipocytes } \downarrow \text { COX-2 induction } \downarrow\end{array}$ & $\begin{array}{l}\text { Monocyte activation, cytokine \& PG } \\
\text { release } \downarrow \text { PMN priming, apoptosis and } \\
\text { oxidative burst; T-cell apoptosis, clonal } \\
\text { regulation \& T-cell receptor } \downarrow \text { Endothelial- } \\
\text { cell adhesion molecule expression, } \\
\text { cytokine release } \downarrow \text { synovial fibroblast } \\
\text { proliferation, collagen synthesis, MMP \& } \\
\text { cytokine release } \downarrow \text { Adipocyte FFA release } \\
\uparrow\end{array}$ & $\begin{array}{l}\text { Negative: Immune cell activity } \downarrow \text { : switch } \\
\text { from phase } 1 \text { to } 2 \downarrow\end{array}$ \\
\hline $\begin{array}{l}\text { Biological agents:IL- } \\
1 \text { blocker } \\
{[54,103-105]}\end{array}$ & $\begin{array}{l}\text { IL-1 signalling of monocytes, B-cells, } \\
\text { endothelial cell, synovial fibroblasts, } \\
\text { chrondrocytes } \downarrow \text { COX-2 induction } \downarrow\end{array}$ & $\begin{array}{l}\text { Synovial fibroblast cytokine, chemokine, } \\
\text { MMP, iNOS \& PG release } \downarrow \text { Mono's } \\
\text { cytokine, ROI \& PG release } \downarrow \text { Osteoclast } \\
\text { activity } \uparrow G A G \text { synthesis } \downarrow \text {, iNOS } \uparrow \text {, MMP } \\
\& \text { aggrecanaseEndothelial-cell adhesion } \\
\text { molecule expression } \downarrow\end{array}$ & $\begin{array}{l}\text { Negative: Immune cell activity } \downarrow \text { : switch } \\
\text { from phase } 1 \text { to } 2 \downarrow\end{array}$ \\
\hline
\end{tabular}

causing suboptimal inflammation and possibly inflammation perpetuation [104].

\section{Discussion}

Long-term activity of the IIS results in low-grade inflammation and chronic disease. Over the past years, ideas regarding the treatment of inflammation have started to change as evidence accumulates which shows that, although the targeting of infiltrating immune cells can control the inflammatory response, it does not lead to its complete resolution and a return to homeostasis, which is essential for healthy tissue and good health in general.
Hotamisligil describes how low-grade, chronic inflammation ('meta-inflammation') induced by a nutritional and metabolic surplus, is accompanied by disturbed metabolic pathways and chronic metabolic disorders. He states that this inflammatory response differs from the classical inflammation response caused by injury [117]. However, others have shown that the classical response of the IIS dealing with injuries can be linked to activation of the central stress axes [26,28]. This article specifically discusses the relationship between the over-activated systemic stress system and the self-limited process of inflammation, known as Resoleomics, executed and controlled by the innate immune system (IIS). 
Changes in lifestyle which are new to our evolutionary process should be considered a major trigger in causing chronic activation of the IS and consequently of the central stress axes and vice versa, thereby leading to chronic diseases such as cardiovascular diseases (CVD), diabetes, respiratory diseases, mental disorders, auto-immune diseases (AID) and cancers. This article evaluates two of the lifestyle changes which contribute to long-term activity of the ISS, namely, nutrition and continuous psycho-emotional stress. Other risk factors such as physical inactivity [6], genetic susceptibility [118], smoking, environmental toxicity and shift work [119] fall beyond the scope of this article but should not be ruled out.

Nutrition is an important factor in understanding the development of chronic inflammation. The current Western diet can disturb the resolution response in various ways (Figure 6). In the Ancestral human diet, foodstuffs with an increased risk of inflammation were virtually unknown, while nutrients able to activate the IIS are now abundant in our diet $[38,120]$. Cordain's research has focused on relating these anti-nutrients in food (eg lectines, saponines) to the development of chronic inflammation and autoimmune diseases (AID) [7,39]. Fortunately, it seems that the human body possesses a strong capacity to recover from illness. If our genes are exposed to their 'original' environment by intake of an ancestral human diet, their function can recover rapidly. Research has shown that obese persons improve their blood markers after just
10 days following a paleolithic diet consisting of fish, lean meat, fruit, vegetables and nuts [121]. Similar results have been found in a study with aboriginals suffering from Diabetes II, who showed normalized blood markers after returning to their traditional lifestyle for seven weeks [122].

People suffering from chronic inflammatory disease demonstrate over-activated central stress axes, which then lead to catecholamines, cortisol and insulin resistance. McGowan et al [123] show the impact of childhood abuse on the epigenetic pattern of different genes including the gene for GR in the hippocampus. They found a decreased level of GR and an increased methylation pattern of the GR gene, giving rise to a situation of lower cortisol sensibility and altered HPA stress responses. This could make people more vulnerable to developing diseases. An altered sensitivity to cortisol has been linked to diseases such as rheumatoid arthritis (RA) [124], post-traumatic stress syndrome [125], chronic fatigue syndrome [126], inflammatory diseases and AID in general [127].

The key priority in the treatment of people with chronic inflammation is to induce the Eicosanoid Switch to the anti-inflammatory resolution phase. Long-lasting cortisol resistance and insulin resistance will definitely delay or block complete resolution. The combination of local factors (ie DHA deficiency, low levels of protectins) disturbing the process of complete resolution (ie Resoleomics) and the absence of adequate NE and cortisol

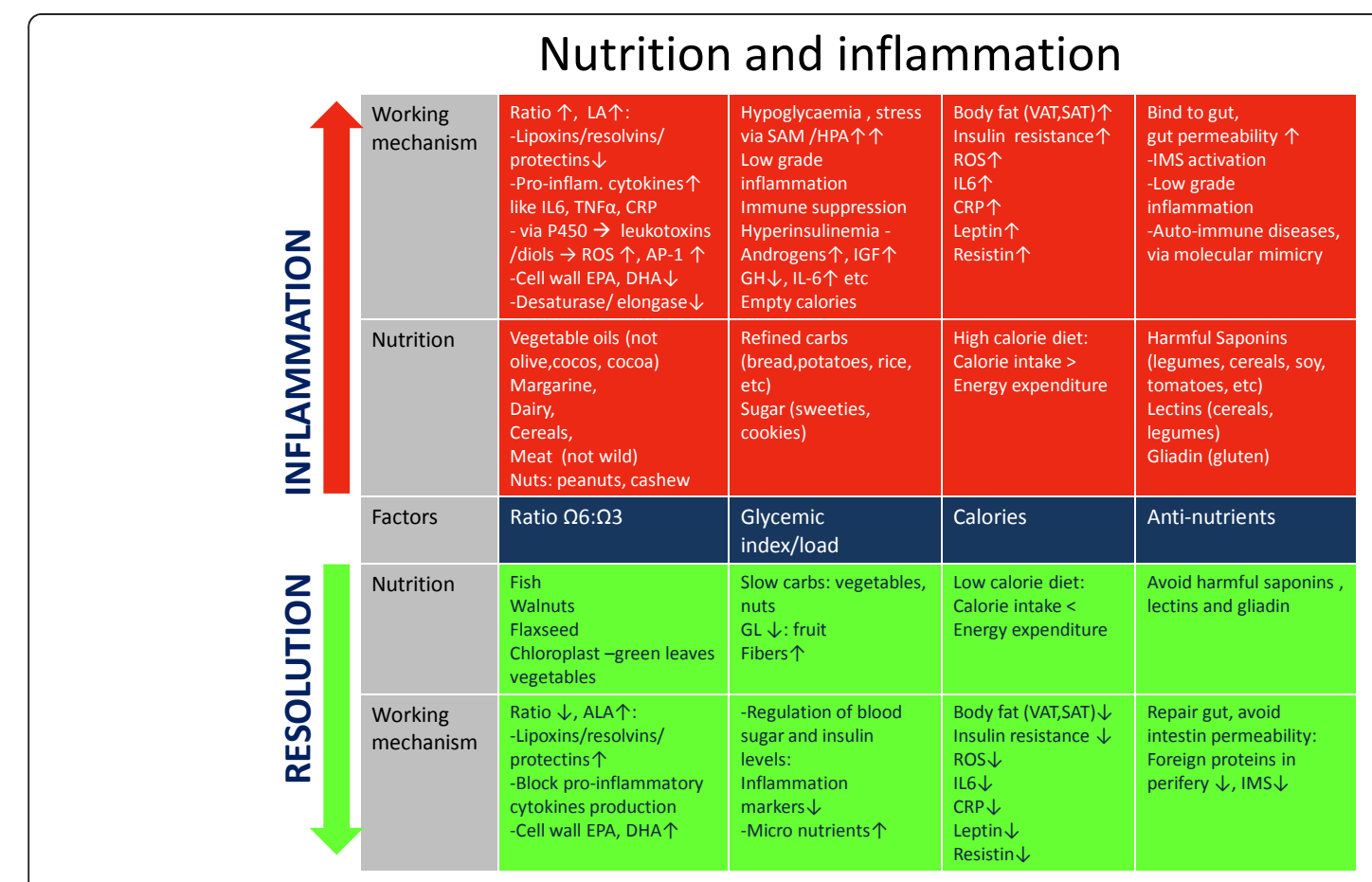

Figure 6 Reflection of the working mechanism demonstrating how several nutritional factors could induce and inhibit inflammation 


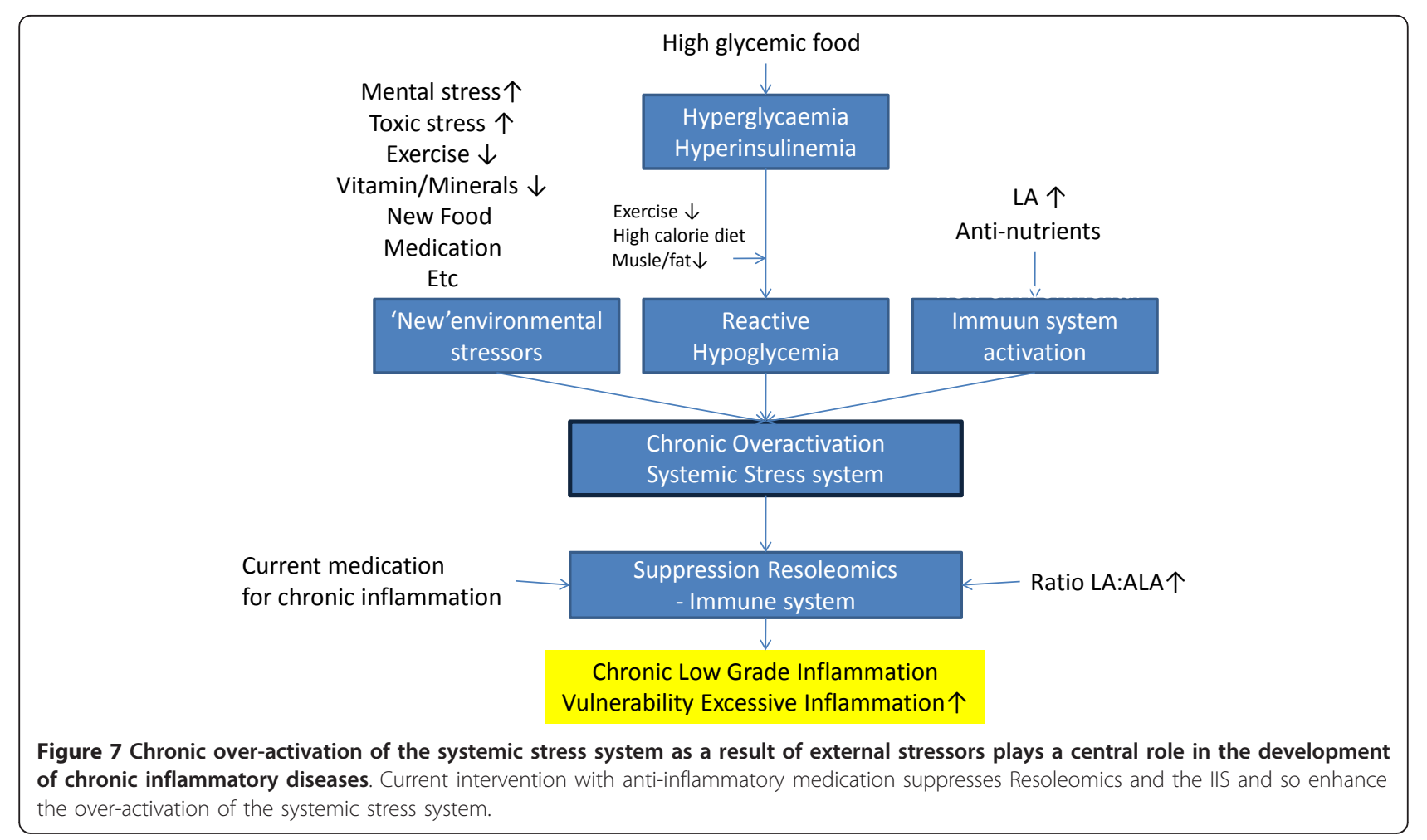

signalling can be responsible for perpetuatual inflammation by delaying the resolution phase of the inflammatory response (Figure 7).

Current anti-inflammatory medication used in RA treatment is aimed at the suppression of the IIS and its inflammatory response and thus hinders Resoleomics. In addition, these medication interventions do not solve underlying catecholamine, cortisol and insulin resistance, and consequently making it impossible to achieve full recovery of the chronic inflammation. This suggests that chronic use of anti-inflammatory medication in fact impedes the body from making a full recovery. Furthermore, the ongoing low-grade inflammation will continuously trigger the activity of the systemic stress system [28].

Health care should focus on early detection of silent, ongoing and low-grade inflammation in order to avoid the development of many chronic diseases. Further research is needed to validate a questionnaire which addresses early symptoms of chronic low-grade inflammation, ie avoidance of exercise, fatigue, emotional flatness, social isolation, decreased libido, hyper or hyposomnia, obsessive behaviour or sensitivity to addiction $[6,128]$.

We have made an effort to demonstrate that the science of Resoleomics can help to find new ways to treat people suffering from diseases based on chronic inflammation. Since over-activated central stress axes directly delay Resoleomics, and thereby delay the resolution of inflammation, treatment should focus on restoring the central stress system to its default, healthy homeostasis.
Dietary changes, psycho-emotional stress release and physical activity should always be included in treatment of all chronic inflammatory diseases.

\section{Abbreviations}

AA: Arachidonic acid; Ach: Acetylcholine; AID: Autoimmune diseases; ALA: alinolenic acid; ALX/FPR2: Lipoxin A(4) receptor; ANXA 1: Annexin 1 protein; AP-1: Activator protein 1; ASA: Aspirin; ATLs: Stable aspirin-triggered lipoxin; COX: Cyclo-oygenase; CRP: High sensitive-C- Reactive Protein; CVD: Cardiovascular diseases; DHA: Docosahexaenoic acid; DMARDs: Disease Modifying Drugs; EPA: Eicosapentaenoic acid; Gl, Glycemic index; GL: Glycemic load; GCs: Glucocorticoids; HPA: Hypothalamus-pituitary-adrenal; IGF-1: Insulin growth factor-1; IS: Immune system; IIS: Innate immune system; IL: Interleukin; LA: a-linoleic acid; LC: Locus Coeruleus; LOX: Lipoxygenase; LK: Leukotoxins; LTs: Leukotrienes; LTD: Leukotoxin diol; LXs: Lipoxins; MTX: Methotrexate; NE: Norepinephrine (ie noradrenaline); NF-kB: Nuclear factorKappaB; NSAIDs: Nonsteroidal anti-inflammatory drugs; PCOS: Polycystic ovarian syndrome; PGs/PGE2/PGD2/PGF2a: Prostaglandins/prostaglandin E2, D2, F2a; PLA2: Phospholipase A2 enzyme; PMNs: Polymorphonuclear leukocytes; PUFAs: Polyunsaturated fatty acids; RA: Rheumatoid arthritis; SAM: Sympathetic-adrenal-medulla; SFA: Saturated fatty acids; SNS: Sympathetic nervous system; TNF: Tumour necrosis factor.

\section{Authors' contributions}

MMB executed an analysis and review of the relationship between chronic inflammatory pathways and the central stress systems, Resoleomics and nutrition. MMB also drafted the manuscript. MLVW reviewed the MOA of currently used anti-inflammatory medication and its effect on Resoleomics. LP played a central role in integrating the results of various stressors on chronic inflammation pathways and also acted as lead reviewer. All authors have approved the final manuscript.

\section{Authors' information}

$M M B$ and MLVW, MD treat patients with chronic diseases in a private practice. $L P$, a practising psychoneuroimmunologist and associate Professor at the University of Gerona, Spain, has developed valuable insights into the 
metabolic pathways of chronic diseases, which he has applied in the treatment of numerous patients.

\section{Competing interests}

The authors declare that they have no competing interests.

Received: 14 November 2011 Accepted: 17 April 2012

Published: 17 April 2012

\section{References}

1. Kolb H, Mandrup-Poulsen T: The global diabetes epidemic as a consequence of lifestyle-induced low-grade inflammation. Diabetologia 2010, 53:10-20.

2. Miller AH, Maletic $V$, Raison $\mathrm{CL}$ : Inflammation and its discontents: the role of cytokines in the pathophysiology of major depression. Biol Psychiatry 2009, 65:732-741.

3. Serhan $\mathrm{CN}$, Chiang $\mathrm{N}$ : Novel endogenous small molecules as the checkpoint controllers in inflammation and resolution: entree for resoleomics. Rheum Dis Clin North Am 2004, 30:69-95.

4. Macaulay V, Richards M, Hickey E, Vega E, Cruciani F, Guida V, Scozzari R, Bonne-Tamir B, Sykes B, Torroni A: The emerging tree of West Eurasian mtDNAs: a synthesis of control-region sequences and RFLPs. Am J Hum Genet 1999, 64:232-249.

5. Smith $\mathrm{E}$, Morowitz $\mathrm{HJ}$ : Universality in intermediary metabolism. Proc Natl Acad Sci USA 2004, 101:13168-13173.

6. Pruimboom L: Physical inactivity is a disease synonymous for a nonpermissive brain disorder. Med Hypothesis 2011, 77:708-713.

7. Cordain L, Toohey L, Smith MJ, Hickey MS: Modulation of immune function by dietary lectins in rheumatoid arthritis. Br J Nutr 2000, 83:207-217.

8. Straub $\mathrm{RH}$, Cutolo $\mathrm{M}$, Buttgereit $\mathrm{F}$, Pongratz $\mathrm{G}$ : Energy regulation and neuroendocrine-immune control in chronic inflammatory diseases. $J$ Intern Med 2010, 267:543-560.

9. Peters A, Hitze B, Langemann D, Bosy-Westphal A, Muller MJ: Brain size, body size and longevity. Int J Obes 2005, 34:1349-1352.

10. Nathan C, Ding A: Nonresolving inflammation. Cell 2010, 140:871-882.

11. Serhan CN: Resolution phase of inflammation: novel endogenous antiinflammatory and proresolving lipid mediators and pathways. Annu Rev Immunol 2007, 25:101-137.

12. Muskiet FAJ: The evolutionairy background, cause and consequences of chronic system low grade inflammation. Significance for clinical chemistry. Ned Tijdschr Klin Chem Labgeneesk 2011, 36:199-214.

13. Bannenberg GL, Chiang N, Ariel A, Arita M, Tjonahen E, Gotlinger KH, Hong S, Serhan CN: Molecular circuits of resolution: formation and actions of resolvins and protectins. J Immunol 2005, 174:4345-4355.

14. Gilroy DW, Colville-Nash PR, Willis D, Chivers J, Paul-Clark MJ, Willoughby DA: Inducible cyclooxygenase may have anti-inflammatory properties. Nat Med 1999, 5:698-701.

15. Serhan CN, Maddox JF, Petasis NA, Akritopoulou-Zanze I, Papayianni A, Brady HR, Colgan SP, Madara JL: Design of lipoxin A4 stable analogs that block transmigration and adhesion of human neutrophils. Biochemistry 1995, 34:14609-14615.

16. Serhan CN, Yang R, Martinod K, Kasuga K, Pillai PS, Porter TF, Oh SF, Spite M: Maresins: novel macrophage mediators with potent antiinflammatory and proresolving actions. J Exp Med 2009, 206:15-23.

17. Willoughby DA, Moore AR, Colville-Nash PR: COX-1, COX-2, and COX-3 and the future treatment of chronic inflammatory disease. Lancet 2000, 355:646-648.

18. Maddox JF, Serhan CN: Lipoxin A4 and B4 are potent stimuli for human monocyte migration and adhesion: selective inactivation by dehydrogenation and reduction. J Exp Med 1996, 183:137-146.

19. Maderna P, Godson C: Taking insult from injury: lipoxins and lipoxin receptor agonists and phagocytosis of apoptotic cells. Prostaglandins Leukot Essent Fatty Acids 2005, 73:179-187.

20. Miller GE, Chen E, Sze J, Marin T, Arevalo JM, Doll R, Ma R, Cole SW: A functional genomic fingerprint of chronic stress in humans: blunted glucocorticoid and increased NF-kappaB signaling. Biol Psychiatry 2008, 64:266-272.

21. Rosas-Ballina M, Tracey KJ: The neurology of the immune system: neural reflexes regulate immunity. Neuron 2009, 64:28-32.
22. Elenkov IJ: Neurohormonal-cytokine interactions: implications for inflammation, common human diseases and well-being. Neurochem Int 2008, 52:40-51.

23. Elenkov IJ, Wilder RL, Chrousos GP, Vizi ES: The sympathetic nerve-an integrative interface between two supersystems: the brain and the immune system. Pharmacol Rev 2000, 52:595-638.

24. Kin NW, Sanders VM: It takes nerve to tell T and B cells what to do. J Leukoc Biol 2006, 79:1093-1104.

25. Peters A, Schweiger U, Pellerin L, Hubold C, Oltmanns KM, Conrad M, Schultes B, Born J, Fehm HL: The selfish brain: competition for energy resources. Neurosci Biobehav Rev 2004, 28:143-180.

26. Miller GE, Cohen S, Ritchey AK: Chronic psychological stress and the regulation of pro-inflammatory cytokines: a glucocorticoid-resistance model. Health Psychol 2002, 21:531-541.

27. Guarini S, Cainazzo MM, Giuliani D, Mioni C, Altavilla D, Marini H, Bigiani A Ghiaroni V, Passaniti M, Leone S, et al: Adrenocorticotropin reverses hemorrhagic shock in anesthetized rats through the rapid activation of a vagal anti-inflammatory pathway. Cardiovasc Res 2004, 63:357-365.

28. Wang H, Yu M, Ochani M, Amella CA, Tanovic M, Susarla S, Li JH, Wang H, Yang $\mathrm{H}$, Ulloa $\mathrm{L}$, et al: Nicotinic acetylcholine receptor alpha7 subunit is an essential regulator of inflammation. Nature 2003, 421:384-388.

29. Liezmann C, Klapp B, Peters EM: Stress, atopy and allergy: A re-evaluation from a psychoneuroimmunologic persepective. Dermatol Endocrinol 2011, 3:37-40.

30. Whitaker AM, Sulzer J, Walker E, Mathis K, Molina PE: Sympathetic modulation of the host defense response to infectious challenge during recovery from hemorrhage. Neuroimmunomodulation 2010, 17:349-358.

31. Straub RH: Physiologische Grundlagen. Lehrbuch der klinischen Pathophysiologie komplexer chronischer Erkrankungen. Vandenhoe \& Ruprecht 2006.

32. Rhen T, Cidlowski JA: Antiinflammatory action of glucocorticoids-new mechanisms for old drugs. N Engl J Med 2005, 353:1711-1723.

33. Heim C, Newport DJ, Bonsall R, Miller AH, Nemeroff CB: Altered pituitaryadrenal axis responses to provocative challenge tests in adult survivors of childhood abuse. Am J Psychiatry 2001, 158:575-581.

34. Danese A, Moffitt TE, Pariante CM, Ambler A, Poulton R, Caspi A: Elevated inflammation levels in depressed adults with a history of childhood maltreatment. Arch Gen Psychiatry 2008, 65:409-415.

35. Simmons RA: Role of metabolic programming in the pathogenesis of beta-cell failure in postnatal life. Rev Endocr Metab Disord 2007, 8:95-104.

36. Malcher-Lopes R, Buzzi M: Glucocorticoid-regulated crosstalk between arachidonic acid and endocannabinoid biochemical pathways coordinates cognitive-, neuroimmune-, and energy homeostasis-related adaptations to stress. Vitam Horm 2009, 81:263-313.

37. Pace TW, Hu F, Miller AH: Cytokine-effects on glucocorticoid receptor function: relevance to glucocorticoid resistance and the pathophysiology and treatment of major depression. Brain Behav Immun 2007, 21:9-19

38. Cordain L, Eaton SB, Sebastian A, Mann N, Lindeberg S, Watkins BA, O'Keefe $J \mathrm{H}$, Brand-Miller J: Origins and evolution of the Western diet: health implications for the 21st century. Am J Clin Nutr 2005, 81:341-354

39. Cordain L: Cereal grains: humanity's double-edged sword. World Rev Nutr Diet 1999, 84:19-73.

40. Patel B, Schutte R, Sporns P, Doyle J, Jewel L, Fedorak RN: Potato glycoalkaloids adversely affect intestinal permeability and aggravate inflammatory bowel disease. Inflamm Bowel Dis 2002, 8:340-346.

41. Vasconcelos IM, Oliveira JT: Antinutritional properties of plant lectins. Toxicon 2004, 44:385-403.

42. Simopoulos AP: Overview of evolutionary aspects of omega 3 fatty acids in the diet. World Rev Nutr Diet 1998, 83:1-11.

43. Simopoulos AP: Evolutionary aspects of diet, the omega-6/omega-3 ratio and genetic variation: nutritional implications for chronic diseases. Biomed Pharmacother 2006, 60:502-507.

44. Guebre-Egziabher F, Rabasa-Lhoret R, Bonnet F, Bastard JP, Desage M, Skilton MR, Vidal H, Laville M: Nutritional intervention to reduce the $n-6 /$ n-3 fatty acid ratio increases adiponectin concentration and fatty acid oxidation in healthy subjects. Eur J Clin Nutr 2008, 62:1287-1293.

45. Liou YA, King DJ, Zibrik D, Innis SM: Decreasing linoleic acid with constant alpha-linolenic acid in dietary fats increases ( $n-3)$ eicosapentaenoic acid in plasma phospholipids in healthy men. J Nutr 2007, 137:945-952. 
46. Wang L, Reiterer G, Toborek M, Hennig B: Changing ratios of omega- 6 to omega-3 fatty acids can differentially modulate polychlorinated biphenyl toxicity in endothelial cells. Chem Biol Interact 2008, 172:27-38.

47. Chene G, Dubourdeau M, Balard P, Escoubet-Lozach L, Orfila C, Berry A, Bernad J, Aries MF, Charveron M, Pipy B: $n-3$ and n-6 polyunsaturated fatty acids induce the expression of COX-2 via PPARgamma activation in human keratinocyte HaCaT cells. Biochim Biophys Acta 2007, 1771:576-589.

48. Ghosh S, Novak EM, Innis SM: Cardiac proinflammatory pathways are altered with different dietary n-6 linoleic to $n-3$ alpha-linolenic acid ratios in normal, fat-fed pigs. Am J Physiol Heart Circ Physiol 2007, 293: H2919-H2927.

49. Riediger ND, Azordegan N, Harris-Janz S, Ma DW, Suh M, Moghadasian MH: 'Designer oils' low in $n-6: n-3$ fatty acid ratio beneficially modifies cardiovascular risks in mice. Eur J Nutr 2009, 48:307-314

50. Nakamura MT, Nara TY: Structure, function, and dietary regulation of delta6, delta5, and delta9 desaturases. Annu Rev Nutr 2004, 24:345-376.

51. Calder PC: Session 3: Joint Nutrition Society and Irish Nutrition and Dietetic Institute Symposium on 'Nutrition and autoimmune disease' PUFA, inflammatory processes and rheumatoid arthritis. Proc Nutr SoC 2008, 67:409-418.

52. Ferrucci L, Cherubini A, Bandinelli S, Bartali B, Corsi A, Lauretani F, Martin A, Andres-Lacueva C, Senin U, Guralnik JM: Relationship of plasma polyunsaturated fatty acids to circulating inflammatory markers. J Clin Endocrinol Metab 2006, 91:439-446.

53. Adam O, Tesche A, Wolfram G: Impact of linoleic acid intake on arachidonic acid formation and eicosanoid biosynthesis in humans. Prostaglandins Leukot Essent Fatty Acids 2008, 79:177-181.

54. Mclnnes IB, Schett G: Cytokines in the pathogenesis of rheumatoid arthritis. Nat Rev Immunol 2007, 7:429-442

55. Viswanathan S, Hammock BD, Newman JW, Meerarani P, Toborek M Hennig B: Involvement of CYP 2 C9 in mediating the proinflammatory effects of linoleic acid in vascular endothelial cells. J Am Coll Nutr 2003, 22:502-510.

56. Mangan DF, Taichman NS, Lally ET, Wahl SM: Lethal effects of Actinobacillus actinomycetemcomitans leukotoxin on human T lymphocytes. Infect Immun 1991, 59:3267-3272.

57. Dickinson S, Hancock DP, Petocz P, Ceriello A, Brand-Miller J: High-glycemic index carbohydrate increases nuclear factor-kappaB activation in mononuclear cells of young, lean healthy subjects. Am J Clin Nutr 2008, 87:1188-1193.

58. Liu S, Manson JE, Buring JE, Stampfer MJ, Willett WC, Ridker PM: Relation between a diet with a high glycemic load and plasma concentrations of high-sensitivity C-reactive protein in middle-aged women. Am J Clin Nutr 2002, 75:492-498.

59. Hu Y, Block G, Norkus EP, Morrow JD, Dietrich M, Hudes M: Relations of glycemic index and glycemic load with plasma oxidative stress markers. Am J Clin Nutr 2006, 84:70-76, quiz:266-267.

60. Esposito K, Marfella R, Ciotola M, Di Palo C, Giugliano F, Giugliano G, D'Armiento M, D'Andrea F, Giugliano D: Effect of a mediterranean-style diet on endothelial dysfunction and markers of vascular inflammation in the metabolic syndrome: a randomized trial. JAMA 2004, 292:1440-1446.

61. Du H, van der AD, van Bakel MM, van der Kallen CJ, Blaak EE, van Greevenbroek MM, Jansen EH, Nijpels G, Stehouwer CD, Dekker JM, Feskens EJ: Glycemic index and glycemic load in relation to food and nutrient intake and metabolic risk factors in a Dutch population. $\mathrm{Am} J$ Clin Nutr 2008, 87:655-661.

62. Pereira MA, Swain J, Goldfine AB, Rifai N, Ludwig DS: Effects of a lowglycemic load diet on resting energy expenditure and heart disease risk factors during weight loss. JAMA 2004, 292:2482-2490.

63. Halton TL, Willett WC, Liu S, Manson JE, Albert CM, Rexrode K, Hu FB: Lowcarbohydrate-diet score and the risk of coronary heart disease in women. N Engl J Med 2006, 355:1991-2002.

64. Cordain L, Eades MR, Eades MD: Hyperinsulinemic diseases of civilization: more than just Syndrome X. Comp Biochem Physiol A Mol Integr Physiol 2003, 136:95-112.

65. Nappo F, Esposito K, Cioffi M, Giugliano G, Molinari AM, Paolisso G, Marfella R, Giugliano D: Postprandial endothelial activation in healthy subjects and in type 2 diabetic patients: role of fat and carbohydrate meals. J Am Coll Cardiol 2002, 39:1145-1150.

66. Ehrmann DA: Polycystic ovary syndrome. N Engl J Med 2005, 352:1223-1236.
67. Goodwin PJ, Ennis M, Bahl M, Fantus IG, Pritchard KI, Trudeau ME, Koo J, Hood N: High insulin levels in newly diagnosed breast cancer patients reflect underlying insulin resistance and are associated with components of the insulin resistance syndrome. Breast Cancer Res Treat 2009, 114:517-525

68. Tran TT, Naigamwalla D, Oprescu Al, Lam L, McKeown-Eyssen G, Bruce WR, Giacca A: Hyperinsulinemia, but not other factors associated with insulin resistance, acutely enhances colorectal epithelial proliferation in vivo. Endocrinology 2006, 147:1830-1837.

69. Smith RN, Mann NJ, Braue A, Makelainen H, Varigos GA: A low-glycemicload diet improves symptoms in acne vulgaris patients: a randomized controlled trial. Am J Clin Nutr 2007, 86:107-115.

70. Matilainen V, Laakso M, Hirsso P, Koskela P, Rajala U, KeinanenKiukaanniemi S: Hair loss, insulin resistance, and heredity in middle-aged women. A population-based study. J Cardiovasc Risk 2003, 10:227-231.

71. Barth JH, Ng LL, Wojnarowska F, Dawber RP: Acanthosis nigricans, insulin resistance and cutaneous virilism. Br J Dermatol 1988, 118:613-619.

72. Peters A, Langemann D: Build-ups in the supply chain of the brain: on the neuroenergetic cause of obesity and type 2 diabetes mellitus. Front Neuroenergetics 2009, 1:2.

73. Gaujoux-Viala C, Smolen JS, Landewe R, Dougados M, Kvien TK, Mola EM, Scholte-Voshaar M, van Riel P, Gossec L: Current evidence for the management of rheumatoid arthritis with synthetic disease-modifying antirheumatic drugs: a systematic literature review informing the EULAR recommendations for the management of rheumatoid arthritis. Ann Rheum Dis 2010, 69:1004-1009.

74. Filer A, Pitzalis C, Buckley CD: Targeting the stromal microenvironment in chronic inflammation. Curr Opin Pharmacol 2006, 6:393-400.

75. Das UN: Vagal nerve stimulation in prevention and management of coronary heart disease. World J Cardiol 2010, 3:105-110.

76. Desneves KJ, Todorovic BE, Cassar A, Crowe TC: Treatment with supplementary arginine, vitamin $C$ and zinc in patients with pressure ulcers: a randomised controlled trial. Clin Nutr (Edinburgh, Scotland) 2005, 24:979-987.

77. Perretti M, Chiang N, La M, Fierro IM, Marullo S, Getting SJ, Solito E, Serhan CN: Endogenous lipid- and peptide-derived anti-inflammatory pathways generated with glucocorticoid and aspirin treatment activate the lipoxin A4 receptor. Nat Med 2002, 8:1296-1302.

78. Roth GJ, Stanford N, Majerus PW: Acetylation of prostaglandin synthase by aspirin. Proc Natl Acad Sci USA 1975, 72:3073-3076.

79. Serhan CN: Lipoxins and aspirin-triggered 15-epi-lipoxins are the first lipid mediators of endogenous anti-inflammation and resolution. Prostaglandins Leukot Essent Fatty Acids 2005, 73:141-162.

80. Gilroy DW: The role of aspirin-triggered lipoxins in the mechanism of action of aspirin. Prostaglandins Leukot Essent Fatty Acids 2005, 73:203-210

81. Claria J, Serhan CN: Aspirin triggers previously undescribed bioactive eicosanoids by human endothelial cell-leukocyte interactions. Proc Natl Acad Sci USA 1995, 92:9475-9479.

82. Paul-Clark MJ, Van Cao T, Moradi-Bidhendi N, Cooper D, Gilroy DW: 15-epilipoxin A4-mediated induction of nitric oxide explains how aspirin inhibits acute inflammation. J Exp Med 2004, 200:69-78.

83. Serhan CN, Takano T, Chiang N, Gronert K, Clish CB: Formation of endogenous "antiinflammatory" lipid mediators by transcellular biosynthesis: Lipoxins and aspirin-triggered lipoxins inhibit neutrophil recruitment and vascular permeability. Am J Respir Crit Care Med 2000, 161:S95-S101.

84. Bertolini A, Ottani A, Sandrini M: Dual acting anti-inflammatory drugs: a reappraisal. Pharmacol Res 2001, 44:437-450

85. Warner TD, Mitchell JA: Cyclooxygenases: new forms, new inhibitors, and lessons from the clinic. FASEB J 2004, 18:790-804.

86. Wahl C, Liptay S, Adler G, Schmid RM: Sulfasalazine: a potent and specific inhibitor of nuclear factor kappa B. J Clin Invest 1998, 101:1163-1174.

87. Barnes PJ: Anti-inflammatory actions of glucocorticoids: molecular mechanisms. Clin Sci (Lond) 1998, 94:557-572.

88. Genestier L, Paillot R, Quemeneur L, Izeradjene K, Revillard JP: Mechanisms of action of methotrexate. Immunopharmacology 2000, 47:247-257.

89. Baggott JE, Morgan SL, Ha TS, Alarcon GS, Koopman WJ, Krumdieck CL: Antifolates in rheumatoid arthritis: a hypothetical mechanism of action. Clin Exp Rheumatol 1993, 11(Suppl 8):S101-S105.

90. Chan ES, Cronstein BN: Methotrexate-how does it really work? Nat Rev Rheumatol 2010, 6:175-178. 
91. Cronstein BN: Molecular therapeutics. Methotrexate and its mechanism of action. Arthritis Rheum 1996, 39:1951-1960.

92. Cronstein BN, Naime D, Ostad E: The antiinflammatory mechanism of methotrexate. Increased adenosine release at inflamed sites diminishes leukocyte accumulation in an in vivo model of inflammation. J Clin Invest 1993, 92:2675-2682.

93. Herman S, Zurgil N, Deutsch M: Low dose methotrexate induces apoptosis with reactive oxygen species involvement in T lymphocytic cell lines to a greater extent than in monocytic lines. Inflamm Res 2005, 54:273-280.

94. Herman S, Zurgil N, Langevitz P, Ehrenfeld M, Deutsch M: he immunosuppressive effect of methotrexate in active rheumatoid arthritis patients vs. its stimulatory effect in nonactive patients, as indicated by cytometric measurements of CD4+ T cell subpopulations. Immunol Invest 2004, 33:351-362.

95. Kim YJ, Song M, Ryu JC: Mechanisms underlying methotrexate-induced pulmonary toxicity. Expert Opin Drug Saf 2009, 8:451-458.

96. Nesher G, Moore TL: The in vitro effects of methotrexate on peripheral blood mononuclear cells. Modulation by methyl donors and spermidine. Arthritis Rheum 1990, 33:954-959.

97. Olsen NJ, Callahan LF, Pincus T: Immunologic studies of rheumatoid arthritis patients treated with methotrexate. Arthritis Rheum 1987, 30:481-488.

98. Olsen NJ, Murray LM: Antiproliferative effects of methotrexate on peripheral blood mononuclear cells. Arthritis Rheum 1989, 32:378-385.

99. Phillips DC, Woollard KJ, Griffiths HR: The anti-inflammatory actions of methotrexate are critically dependent upon the production of reactive oxygen species. Br J Pharmacol 2003, 138:501-511.

100. Sperling RI, Coblyn JS, Larkin JK, Benincaso Al, Austen KF, Weinblatt ME: Inhibition of leukotriene B4 synthesis in neutrophils from patients with rheumatoid arthritis by a single oral dose of methotrexate. Arthritis Rheum 1990, 33:1149-1155.

101. Thomas R, Carroll GJ: Reduction of leukocyte and interleukin-1 beta concentrations in the synovial fluid of rheumatoid arthritis patients treated with methotrexate. Arthritis Rheum 1993, 36:1244-1252.

102. van Ede $A E$, Laan RF, Blom HJ, De Abreu RA, van de Putte LB: Methotrexate in rheumatoid arthritis: an update with focus on mechanisms involved in toxicity. Semin Arthritis Rheum 1998, 27:277-292.

103. McInnes IB, Gracie JA: Targeting cytokines beyond tumor necrosis factoralpha and interleukin-1 in rheumatoid arthritis. Curr Pain Headache Rep 2005, 9:405-411.

104. Scott DL, Kingsley GH: Tumor necrosis factor inhibitors for rheumatoid arthritis. N Engl J Med 2006, 355:704-712.

105. Raza K, Falciani F, Curnow SJ, Ross EJ, Lee CY, Akbar AN, Lord JM, Gordon C, Buckley CD, Salmon M: Early rheumatoid arthritis is characterized by a distinct and transient synovial fluid cytokine profile of T cell and stromal cell origin. Arthritis Res Ther 2005, 7:R784-R795.

106. Planaguma A, Titos E, Lopez-Parra M, Gaya J, Pueyo G, Arroyo V, Claria J: Aspirin (ASA) regulates 5 -lipoxygenase activity and peroxisome proliferator-activated receptor alpha-mediated CINC-1 release in rat liver cells: novel actions of lipoxin A4 (LXA4) and ASA-triggered 15-epi-LXA4. FASEB J 2002, 16:1937-1939.

107. Bannenberg GL: Therapeutic applicability of anti-inflammatory and proresolving polyunsaturated fatty acid-derived lipid mediators. Sci World J 2010, 10:676-712.

108. Yacoubian S, Serhan CN: New endogenous anti-inflammatory and proresolving lipid mediators: implications for rheumatic diseases. Nat Clin Pract Rheumatol 2007, 3:570-579, quiz 571 p following 589.

109. Basselin M, Ramadan E, Chen M, Rapoport Sl: Anti-inflammatory effects of chronic aspirin on brain arachidonic acid metabolites. Neurochem Res 2011, 36:139-145.

110. Scheinman RI, Cogswell PC, Lofquist AK, Baldwin AS Jr: Role of transcriptional activation of I kappa B alpha in mediation of immunosuppression by glucocorticoids. Science 1995, 270:283-286.

111. MacDermott RP, Schloemann SR, Bertovich MJ, Nash GS, Peters M, Stenson WF: Inhibition of antibody secretion by 5 -aminosalicylic acid. Gastroenterology 1989, 96:442-448.

112. Tanabe T, Tohnai N: Cyclooxygenase isozymes and their gene structures and expression. Prostaglandins Other Lipid Mediat 2002, 68-69:95-114.

113. Miller AH: Depression and immunity: a role for T cells? Brain Behav Immun 2010, 24:1-8.
114. Vane JR: Inhibition of prostaglandin synthesis as a mechanism of action for aspirin-like drugs. Nat New Biol 1971, 231:232-235.

115. Fiorucci S, Distrutti E, de Lima OM, Romano M, Mencarelli A, Barbanti M, Palazzini E, Morelli A, Wallace JL: Relative contribution of acetylated cyclooxygenase (COX)-2 and 5-lipooxygenase (LOX) in regulating gastric mucosal integrity and adaptation to aspirin. FASEB J 2003, 17:1171-1173.

116. Tabor CW, Tabor H: Polyamines. Annu Rev Biochem 1984, 53:749-790.

117. Hotamisligil GS: Inflammation and metabolic disorders. Nature 2006, 444:860-867.

118. Fall CHD: Developmental origins of cardiovascular disease, type 2 diabetes and obesity in humans. Early Life Orig Health Dis 2006, 2:8-28.

119. Egger G, Dixon J: Inflammatory effects of nutritional stimuli: further support for the need for a big picture approach to tackling obesity and chronic disease. Obes Rev 2010, 11:137-149.

120. Eaton SB, Cordain L, Sparling PB: Evolution, body composition, insulin receptor competition, and insulin resistance. Prev Med 2009, 49:283-285.

121. Frassetto LA, Schloetter M, Mietus-Synder M, Morris RC Jr: Sebastian A: Metabolic and physiologic improvements from consuming a paleolithic, hunter-gatherer type diet. Eur J Clin Nutr 2009, 63:947-955.

122. O'Dea K: Marked improvement in carbohydrate and lipid metabolism in diabetic Australian aborigines after temporary reversion to traditional lifestyle. Diabetes 1984, 33:596-603.

123. McGowan PO, Sasaki A, D’Alessio AC, Dymov S, Labonte B, Szyf M, Turecki G, Meaney MJ: Epigenetic regulation of the glucocorticoid receptor in human brain associates with childhood abuse. Nat Neurosci 2009, 12:342-348.

124. Cutolo M, Foppiani L, Minuto F: Hypothalamic-pituitary-adrenal axis impairment in the pathogenesis of rheumatoid arthritis and polymyalgia rheumatica. J Endocrinol Invest 2002, 25:19-23.

125. Strohle A, Scheel M, Modell S, Holsboer F: Blunted ACTH response to dexamethasone suppression-CRH stimulation in posttraumatic stress disorder. J Psychiatr Res 2008, 42:1185-1188.

126. Van Den Eede F, Moorkens G, Van Houdenhove B, Cosyns P, Claes SJ: Hypothalamic-pituitary-adrenal axis function in chronic fatigue syndrome. Neuropsychobiology 2007, 55:112-120.

127. Cobb JM, Steptoe A: Psychosocial stress and susceptibility to upper respiratory tract illness in an adult population sample. Psychosom Med 1996, 58:404-412.

128. Segerstrom SC: Social networks and immunosuppression during stress: relationship conflict or energy conservation? Brain Behav Immun 2008, 22:279-284.

\section{doi:10.1186/1743-7075-9-32}

Cite this article as: Bosma-den Boer et al:: Chronic inflammatory diseases are stimulated by current lifestyle: how diet, stress levels and medication prevent our body from recovering. Nutrition \& Metabolism 2012 9:32.

\section{Submit your next manuscript to BioMed Central and take full advantage of:}

- Convenient online submission

- Thorough peer review

- No space constraints or color figure charges

- Immediate publication on acceptance

- Inclusion in PubMed, CAS, Scopus and Google Scholar

- Research which is freely available for redistribution

Submit your manuscript at www.biomedcentral.com/submit
C) Biomed Central 